Published by LPMP Imperium

Journal homepage: https:/ / ejournal.imperiuminstitute.org/ index.php/AKURASI

\title{
MODEL ALTMAN Z-SCORE TERHADAP KINERJA KEUANGAN DI BURSA EFEK INDONESIA MELALUI PENDEKATAN REGRESI LOGISTIK
}

Nurul Fitri ${ }^{1}$, Rachma Zannati ${ }^{2 *}$

1Fakultas Ekonomi dan Bisnis Islam Attahiriyah, Jakarta, Indonesia. 2,Sekolah Tinggi Ilmu Ekonomi Indonesia, Jakarta, Indonesia.

\begin{abstract}
The purpose of this study is to confirm the determinants of financial performance on the condition of financial distress companies through the Altman Model (Z-score) approach. The sample in this study is a manufacturing industry sub-sector company which is listed on the Indonesia Stock Exchange for the period 2013 to 2017. The analysis technique of this study uses logistic regression analysis, and the findings prove that the Current Ratio and Debt to Equity Ratio cannot predict the condition of Financial Distress. Whereas Return On Assets can predict Financial Distress in manufacturing companies. The implications of this finding can contribute to companies in maintaining financial performance stability so as to avoid financial distress.
\end{abstract}

Keywords: financial distress, financial performance, Altman Z-sore

\begin{abstract}
Abstrak
Tujuan dari penelitian ini adalah untuk mengkonfirmasi faktor determinan dari kinerja keuangan terhadap kondisi perusahaan financial distress melalui pendekatan Model Altman (Z-score). Sampel pada penelitian ini merupakan perusahaan manufaktur sub sektor industri yang listing di Bursa Efek Indonesia untuk periode 2013 sampai 2017. Teknik analisis penelitian ini menggunakan analisis regresi logistik, dan hasil temuan membuktikkan bahwa Current Ratio dan Debt to Equity Ratio tidak dapat memprediksi kondisi Financial Distress. Sedangkan Return On Asset dapat memprediksi Financial Distress pada perusahaan manufaktur. Implikasi temuan ini dapat memberikan kontribusi bagi perusahaan dalam mempertahankan stabilitas kinerja keuangan sehingga terhindar dari financial distress.
\end{abstract}

Kata Kunci: Financial Distress, Kinerja Keuangan, Altman Z-Score

Email korespondensi: rachmaznt@gmail.com

Pedoman Sitasi: Fitri, N., \& Zannati, R. (2019). Model Altman Z-Score Terhadap Kinerja Keuangan di BEI Melalui Pendekatan Regresi Logistik. AKURASI, 1(1), 63 - 72.

\section{AKURASI}

Paper type

Research paper

Keywords: financial distress, financial performance, Altman Zsore

Received: 30 Jul 2019

Accepted: 07 Aug 2019

Online: 20 Aug 2019

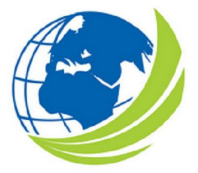

Akurasi: Jurnal Riset Akuntansi dan Keuangan, Vol 1, No.1, Agustus 2019, pp. 63 - 72 e-ISSN: 2685-2888 


\section{PENDAHULUAN}

Tujuan terbentuknya suatu perusahaan dengan harapan mendapatkan keuntungan sehingga mampu bertahan atau berkembang dalam jangka panjang dan tidak mengalami likuiditas. Namun, kenyataannya perusahaan yang sudah beroperasi dalam jangka panjang masih mengalami kondisi kesulitan keuangan yang berdampak terjadinya kebangkrutan.

Salah satu fenomena yang terjadi dalam perusahaan manufaktur di Indonesia pada tahun 2015 adalah delisting. Delisting merupakan suatu kondisi dimana saham yang tercatat pada Bursa Efek Indonesia mengalami penurunan kriteria sehingga tidak memenuhi syarat pencatatan, sehingga saham tersebut dapat dikeluarkan dari pencatatan Bursa Efek Indonesia. Pada tahun 2015 Bursa Efek Indonesia mengeluarkan 3 perusahaan, yaitu PT Davomas Abadi, tbk (DAVO), PT Bank Ekonomi Raharja, tbk (BAEK), dan PT Unitex, tbk (UNTX). Salah satu kriteria pencatatan perusahaan Go-public yang terlisting di BEI yaitu kondisi keungan perusahaan yang sangat mempengaruhi kenaikan atau penurunan nilai saham dari perusahaan. Selain itu, perusahaan manufaktur yang besar sangat tertarik pada kesehatan keuangan Suppliernya untuk menghindari adanya gangguan yang terkait dengan produksi dan skedul distribusi.

Laporan keuangan merupakan salah satu sumber informasi mengenai posisi keuangan, kinerja, dan perubahan posisi keuangan perusahaan yang diterbitkan oleh perusahaan untuk mendukung pengambilan sebuah keputusan yang tepat bagi perusahaan. Agar informasi yang tersaji dalam laporan keuangan dapat lebih bermanfaat untuk pengambilan keputusan, maka laporan keuangan tersebut harus dikonversikan menjadi sebuah informasi yang berguna dalam pengambilan keputusan yang ekonomis. Untuk membuktikan laporan keuangan tersebut bermanfaat bagi para stakeholders, maka perlu dilakukan sebuah penelitian, yaitu menganalisis rasio keuangan untuk memprediksi kinerja keuangan perusahaan seperti kebangkrutan dan financial distress.

Suatu tahap dimana sebuah entitas atau perusahaan mengalami penuruan kondisi keuangan sebelum terjadinya kebangkrutan atau likuidasi, hal tersebut merupakan kondisi financial distress. Financial distress dimulai dengan ketidakmampuan perusahaan memenuhi kewajibannya, terutama kewajiban yang bersifat jangka pendek termasuk kewajiban likuiditas, dan juga kewajiban yang termasuk dalam kategori solvabilitas (Hanifah \& Purwanto, 2013). Dalam hal ini rasio keuangan digunakan untuk memprediksi terjadinya financial distress. Model sistem peringatan untuk mengantisipasi adanya Financial Distress perlu untuk dikembangkan karena model ini dapat digunakan sebagai sarana untuk mengidentifikasi bahkan untuk memperbaiki kondisi sebelum sampai pada kondisi krisis.

Selain itu, adanya perkembangan persaingan perusahaan industri yang semakin ketat menyebabkan biaya yang dikeluarkan perusahaan semakin besar dan menyebabkan semakin meningkatnya Financial Distress perusahaan. Masalah keuangan yang dihadapi suatu perusahaan apabila dibiarkan berlarut - larut akan mengakibatkan terjadinya kebangkrutan. Beberapa perusahaan yang mengalami masalah keuangan mencoba untuk mengatasi masalahanya dengan melakukan penggabungan usaha dan melakukan pinjaman atau sebaliknya menutup usahanya. Oleh karena itu analisis dan prediksi kondisi keuangan perusahaan adalah sangat penting.

Penelitian tentang financial distress dipelopori oleh Altman (1968) yang mengkaji pemanfaatan analisis rasio keuangan sebagai alat untuk memprediksi kebangkrutan perusahaan. Altman mengembangkan metode Z - score yaitu score yang ditentukan dari hitungan standar kali nisbah - nisbah keuangan yang menunjukan tingkat kemungkinan kebangkrutan perusahaan dan model ini dikenal dengan Model Altman. Salah satu kelemahan Z - score adalah terletak pada penggunaan rasio EBIT (Earning Before Interest and Taxes). Pengungkapan dan pelaporan keuangan antara perusahaan satu dengan lainnya biasanya berbeda. Pada perusahaan tertentu ada kalanya besarnya biaya bunga tidak dinyatakan secara eksplisit sehingga EBIT sulit diterapkan, oleh karenanya harus menggunakan EBT (Earning Before Tax), dan berdampak pada beragamnya data EBIT.

Dari beberapa literatur sebelumnya yang menunjukkan bahwa kinerja keuangan $\mathrm{p}$ erusahaan dapat memberikan efek secara langsung terhadap financial distress. Hal tersebut dapat dikonfirmasikan bahwa rasio keuangan yaitu rasio likuiditas berpengaruh dan signifikan terhadap financial distress (Rahmadani, et 
al., 2014; Widhari \& Merkusiwati, 2015; Andre, 2015; Setyobudi, et al., 2016; Gonbevy, 2016; Anggraini, 2017; Setiawan \& Amboningtyas, 2018). Namun berbeda dengan hasil temuan oleh Saleh \& Sudiyatmo, (2013); Arwinda \& Merkusiwati (2014); dan Kholidah \& Mufidah (2016), bahwa rasio likuiditas belum dapat mempegaruhi secara langsung terhadap.

Selain rasio likuiditas yang dapat memberikan kontribusi terhadap kondisi kepailitan perusahaan, rasio solvabilitas (leverage) juga dapat mengukur kemampuan perusahaan dalam memenuhi serta mempertahankan kewajibannya (hutang) secara tepat waktu. Hasil yang ditunjukkan Saleh \& Sudiyatmo (2013); Arwinda \& Merkusiwati (2014); Gonbevy (2016); Kholidah \& Mufidah (2016); dan Anggraini, (2017), bahwa rasio leverage dapat memberikan efek yang signifikan terhadap financial distress. Temuan tersebut, berbeda dengan hasil penelitian yang menyatakan bahwa rasio leverage tidak berpengaruh dan signifikan terhadap financial distress (Arwinda \& Merkusiwati, 2014; Andre, 2015; Widhari \& Merkusiwati, 2015; Setyobudi, et al., 2016; dan Setiawan \& Amboningtyas, 2018).

Tingkat rasio profitabilitas suatu perusahaan dapat berpengaruh dengan kondisi keuangan suatu entitas. Literatur sebelumnya telah membuktikkan bahwa rasio profitabilitas dapat mempengaruhi dan signifikan terhadap kondisi financial distress (Saleh \& Sudiyatmo, 2013; Rahmadani, et al., 2014; Andre , 2015; Setyobudi, et al., 2016; dan Anggraini, 2017). Karena rasio profitabilitas dapat mengukur efektivitas manajemen yang diperoleh berdasarkan besar atau kecilnya keuntungan yang diperoleh, sehingga semakin baik rasio profitabilitas perusahaan, maka akan meningkatkan kemampuan perusahaan dalam memperoleh keuntungan (Fahmi, 2017). Dengan demikian, kemungkinan perusahaan akan mengalami financial distress tidak terlalu besar. Berbeda dengan hasil yang ditunjukkan Kholidah \& Mufidah (2016); dan Setiawan \& Amboningtyas (2018) menyatakan bahwa rasio profitabilitas tidak berpengaruh signifikan terhadap financial distress.

Dari uraian tersebut, penelitian ini dapat memberikan kontribusi bagi perusahaan untuk dapat mempertahankan kinerja keuangan agar tetap dalam kondisi stabil (sehat) dan terhindar dari kondisi financial distress, serta dapat bermanfaat bagi para stakeholder eksternal lainnya yaitu pihak investor dan kreditur dalam menanamkan modal dan mendukung pengelolaan keuangan pada perusahaan tersebut. Dengan demikian, penelitian ini memiliki tujuan untuk dapat mengkonfirmasi faktor determinan dari kinerja keuangan terhadap kondisi perusahaan financial distress melalui pendekatan Model Altman (Zscore).

\section{KAJIAN PUSTAKA DAN MODEL PENELITIAN}

Financial Distress

Kebangkrutan adalah suatu kondisi dimana suatu perusahaan tidak mampu lagi untuk mengoperasikan perusahaan dengan baik karena kesulitan keuangan yang dialami entitas tersebut sudah sangat parah (Prihanthini \& Sari, 2013). Financial distress merupakan proses yang mana perusahaan mengalami kesulitan keuangan, sehingga perusahaan tidak mampu dalam memenuhi kewajibannya. Perusahaan akan mengalami financial distress jika arus kas operasi perusahaan tidak mampu mencukupi pemenuhan kewajiban jangka pendek seperti pembayaran Bunga kredit yang telah jatuh tempo. Semakin besar kewajiban yang dimiliki perusahaan akan menyebabkan semakin besarnya terjadi resiko financial distress. Dengan demikian, financial distress merupakan suatu kondisi dimana peusahaan mengalami kesulitaan untuk memenuhi kewajibanya kepada pihak yang memberi pinjaman (debitur) Sulastri dan Zannati (2018).

\section{Kinerja Keuangan}

Kinerja keuangan merupakan analisis yang digunakan untuk mengukur kondisi keuangan perusahaan yang sesuai dengan standar keuangan yaitu Standar Akuntansi Keuangan yang berbasis International Financial Standard Reporting (IFRS). Menurut Fahmi dalam Sulastri dan Zannati (2018), kinerja keuangan dapat dianalisis melalui lima tahap yaitu review terhadap laporan keuangan, menganalisis seluruh rasio keuangan (perhitungan rasio keuangan), membandingkan hasil perhitungan rasio yang diperoleh, 
interprestasi terhadap masalah yang terjadi di perusahaan, dan pemecahan solusi masalah keuangan. Analisis rasio merupakan pengukuran untuk menilai kinerja laporan keuangan suatu entitas dengan membandingkan pos satu dengan lainnya. Analisis rasio keuangan terdiri dari rasio likuiditas, rasio leverage (solvabilitas), rasio aktivitas, rasio profitabilitas, rasio rentabilitas, dan rasio pasar (nilai pasar) (Kasmir, 2017).

\section{Model Altman (Z-Score)}

Model Atlman Z-score merupakan indikator untuk mengukur potensi kebangkrutan suatu perusahaan. Model Altman menggunakan metode Discriminant Analysis yaitu dengan mengkombinasikan melihat adanya perbedaan antara perusahaan yang bangkrut dan yang tidak bangkrut (Hariyani \& Sujianto, 2018). Rasio keuangan yang dikembangkan oleh Altman yaitu Net Working Capital to Total Assets, Retained Earnings to Total Assets, Earning Before Interest and Tax to Total Assets, Market Value of Equity to Book Value of Debt, dan Sales to Total Assets. Persamaan model Altman yaitu :

\section{$Z=1,2 X_{1}+1,4 X_{2}+3,3 X_{3}+0,6 X_{4}+1,0 X_{5}$}

Keterangan :

$\mathrm{Z}=$ Bankruptcy index

$\mathrm{X} 1$ =Working capital / total asset

$\mathrm{X} 2=$ Retained earnings $/$ total asset

$\mathrm{X} 3=$ Earning before interest and taxes / total asset

$\mathrm{X} 4=$ Market value of equity $/$ book value of total debt

$\mathrm{X} 5=$ Sales $/$ total asset

Hasil dari perhitungan yang diperoleh dari perhitungan Z-Score oleh masing-masing perusahaan akan dikelompokkan sesuai standar nilai kritis oleh Altman, yaitu:

a. Jika nilai $\mathrm{Z}<1,8$ maka termasuk perusahaan yang bangkrut;

b. Jika nilai $1,8<\mathrm{Z}<2,99$ maka termasuk grey area (tidak dapat ditentukan apakah perusahaan tersebut sehat ataupun mengalami kebangkrutan);

c. Jika nilai $Z>2,99$ maka termasuk perusahaan yang tidak bangkrut.

\section{Kerangka Konseptual \& Hipotesis}

Pengaruh Current ratio terhadap kondisi financial distress

Kondisi perusahaan yang mengalami masalah dalam likuiditas, maka memungkinkan akan terdorong dalam fase kesulitan keuangan (financial distress), dan apabila kondisi kritis tersebut berlarut dapat menyebabkan perusahaan pailit (bangkrut) (Fahmi, 2017). Dengan demikian rasio likuiditas mampu menjadi alat prediksi kondisi financial distress suatu perusahaan, salah satunya dengan menganalisis current ratio. Current ratio mampu mengukur kemampuan suatu perusahaan dalam memenuhi hutang jangka pendeknya dengan menggunakan aktiva lancarnya. Semakin besar rasio likuiditas maka semakin kecil kemungkinan perusahaan tersebut mengalami financial distress. Sejalan dengan hasil penelitian Hidayat \& Meiranto (2014), menyimpulkan bahwa Current ratio merupakan rasio keuangan yang paling signifikan dalam memprediksi kondisi Financial distress perusahaan. Dengan demikian, hipotesis yang dapat dirumuskan adalah sebagai berikut:

$\mathrm{H}_{1}$ : Current Ratio berpengaruh terhadap financial distress perusahaan.

Pengaruh return on assets (ROA) terhadap financial distress

Analisis rasio profitabilitas dapat mengukur keefektivan kinerka keuangan manajemen, karena diukur melalui tingkat proporsi besar atau kecilnya keuntungan yang diperoleh, yang memberikan pengaruh terhadap kondisi keuangan yang mengalami kesulitan likuiditas (Fahmi, 2017). Khususnya, rasio return on asset (ROA) dapat memprediksi kondisi financial distress perusahaan. Dalam penelitian yang dilakukan oleh Saleh dan Sudiyatno (2013) membuktikkan bahwa return on asset (ROA) dapat memprediksi terjadinya 
kondisi Financial distress perusahaan. Dengan demikian, hipotesis yang dapat dirumuskan adalah sebagai berikut :

$\mathrm{H}_{2}$ : Return on asset (ROA) Perpengaruh terhadap financial distress perusahaan.

Pengaruh debt to equty ratio terhadap Kondisi financial distress.

Untuk mengukur kemampuan perusahaan dalam memenuhi kewajibannya dalam jangka pendek dan jangka panjang (Sulastri \& Zannati, 2018). Aktivitas perusahaan, lebih banyak menggunakan pinjaman (hutang) dari pihak ketiga dibandingkan dengan mengelola modal sendiri untuk membiayai kegiatan perusahaan. Sehingga, semakin besar pinjaman (hutang), maka resiko terjadinya kebangkrutan akan semakin besar, karena perusahaan akan kesulitan memperoleh pinjaman tambahan untuk menutupi hutang dan perusahaan dikhawatirkan tidak mampu membayar kewajibannya dengan aktiva yang dimilikinya.

Dengan demikian, rasio Debt to Equity Ratio (DER) dapat memprediksi kondisi kebangrutan perusahaan, jika nilai DER tinggi maka semakin besar proporsi hutang terhadap ekuitas perusahaan yang. Berdasarkan hasil penelitian terdahulu bahwa Debt to Equity Ratio (DER) berpengaruh signifikan terhadap terjadinya kondisi financial distress perusahaan (Noviadri, 2015). Sehingga, hipotesis yang dapat dirumuskan adalah sebagai berikut :

$\mathrm{H}_{3}$ : Debt to Equity Ratio (DER) Perpengaruh terhadap financial distress perusahaan.

Berdasarkan uraian di atas maka dapat kerangka konseptual dalam penelitian ini adalah sebagai berikut:

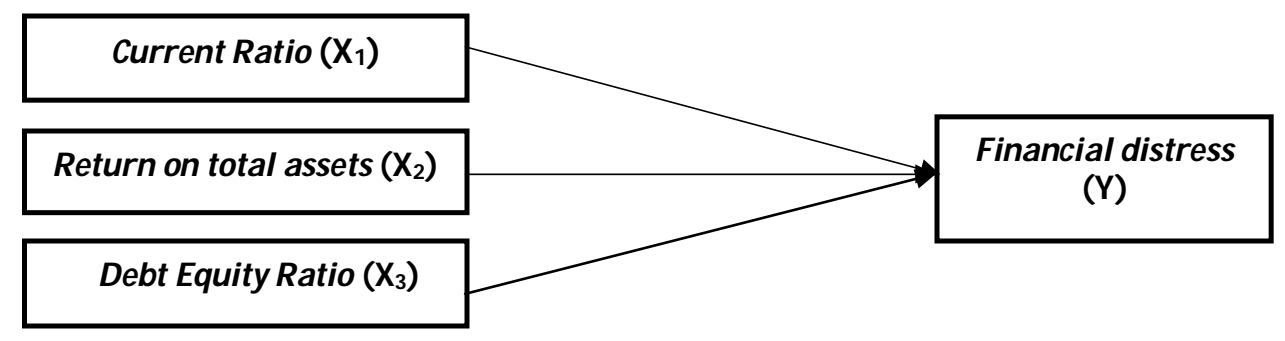

\section{Gambar 1. Kerangka Konseptual}

\section{METODE PENELITIAN}

\section{Desain Penelitian}

Penelitian ini merupakan jenis penelitian kuantitatif yang menggunakan data-data berupa angka/ numerik yaitu dengan menganalisis rasio keuangan perusahaan (Suryani \& Hendryadi, 2015). Objek penelitian ini merupakan perusahaan go public yang sudah terdaftar di Bursa Efek Indonesia (BEI) pada sektor Manufaktur sub sektor Industri tahun 2013 sampai dengan 2017.

Teknik Pengumpulan Data

Teknik pengumpulan data merupakan suatu proses mengumpulkan data yang diperlukan dalam penelitian. Dengan data yang terkumpul untuk menguji hipotesis yang telah dirumuskan. Data yang digunakan dalam penelitian ini merupakan data sekunder yaitu data yang diperoleh dalam bentuk yang sudah jadi atau sudah diolah oleh pihak lain dan sudah dipublikasikan (Suryani \& Hendryadi, 2015). Analisis data yang dilakukan oleh penelitian ini menggunakan data sekunder yang berupa laporan keuangan perusahaan manufaktur sektor industri yang terdaftar dalam Bursa Efek Indonesia. Data diperoleh dari website http:// www.idx.co.id berupa laporan keuangan dan berbagai sumber media lainnya.

\section{Populasi dan Sampel}

Populasi penelitian ini adalah perusahaan manufaktur sektor Industri yang terdaftar di Bursa Efek Indonesia Periode 2013 - 2017 sebanyak 144 Perusahaan Manufaktur. Sampel merupakan bagian dari 
jumlah dan karakteristik yang dimiliki oleh populasi (Sugiyono, 2014). Pada penelitian ini sampel yang diambil adalah 23 perusahaan manufaktur sub sektor industri yang terdaftar di Bursa Efek Indonesia Periode 2013- 2017. Teknik pengambilan sampel yang digunakan dalam penelitian ini adalah metode purposive sampling, yaitu penentuan sampel berdasarkan kriteria tertentu sesuai dengan yang dikehendaki oleh peneliti. Pemilihan sampel dilakuan secara purposive sampling bertujuan untuk mendapatkan sampel yang representative berdasarkan kriteria yang ditentukan.

Pengukuran

Penelitian ini menggunakan variabel Independen yaitu Current Ratio, Return On Assets dan Debt to Equity Ratio. Sedangkan variable Dependen adalah Financial Distress. Definisi dari Variabel Dependen dan Variabel Independen dalam penelitian ini akan dijelaskan sebagai berikut :

Current Ratio. Merupakan rasio yang digunakan untuk mengukur kemampuan perusahaan dalam memenuhi kewajiban jangka pendeknya yang segera jatuh tempo dengan menggunakan total aset lancar yang tersedia (Brigham dan Houston, 2013). Current Ratio ini menggambarkan seberapa besar jumlah ketersediaan aset lancar yang dimiliki perusahaan dibandingkan dengan total kewajiban lancar.

Return On Asset. Merupakan rasio yang menunjukan seberapa besar kontribusi aset dalam menciptakan laba bersih (Brigham dan Houston, 2013). Rasio ini digunakan untuk mengukur seberapa besar jumlah laba bersih yang akan dihasilkan dari setiap rupiah dana yang tertanam dalam aset total.

Debt To Equity Ratio. Merupakan rasio yang digunakan untuk mengukur besarnya proporsi utang terhadap modal. Rasio ini dihitung sebagai hasil bagi antara total utang dengan modal (Brigham dan Houston, 2013). Rasio ini berguna untuk mengetahui besarnya perbandingan antara jumlah dana yang disediakan oleh kreditor dengan jumlah dana yang berasal dari pemilik perusahaan.

Financial Distress. Financial Distress (Kebangkrutan) adalah keadaan dimana memburuknya kondisi keuangan perusahaan sehingga perusahaan tidak dapat menjalankan kegiatan operasional perusahaan dengan baik. Dapat dikatakan kebangkrutan merupakan kegagalan perusahaan dalam menjalankan operasi dan dalam menghasilkan laba. Kegagalan keuangan (Financial Distressed), merupakan kondisi perusahaan yang mana kesulitan dana baik dalam arti dana didalam pengertian kas atau dalam pengertian modal kerja (Brigham dan Houston, 2013). Untuk memperediksi financial distress, penelitian ini menggunakan metode Altman Z-Score yang telah dikembangkan dari tahun 1968, dengan rumus menghitung nilai Z adalah:

\section{$Z=1,2 X_{1}+1,4 X_{2}+3,3 X_{3}+0,6 X_{4}+1,0 X_{5}$}

\section{Teknik Analisis}

Teknik analisis menggunakan analisis Regresi Logistik, Ghozali (2013) menyatakan bahwa logistic regression digunakan untuk menguji apakah probabilitas terjadinya variabel dependen dapat diprediksi oleh variabel independen. Dalam penelitian ini variabel dependen bersifat dummy (menerima opini audit going concern atau tidak menerima opini audit going concern), maka pengujian terhadap hipotesis dilakukan dengan menggunakan uji regresi logistik. Regresi logistik bertujuan untuk melakukan prediksi keanggotaan grup dan menganalisis seberapa jauh model yang digunakan mampu memprediksi secara benar kategori (grup) dari sejumlah sample. persamaan model Regresi logistic dapat di rumuskan sebagai berikut :

$$
\mathrm{FD}=\mathrm{C}+\beta 1 C R+\beta 2 R O A+\beta 3 D E R
$$

Keterangan :

FD = financial distress 
AKURASI, 1(1), 63 - 74

Fitri, N., \& Zannati, R.. Model Altman Z-Score Terhadap....

$\beta 0 \quad=$ konstanta

$\beta 1 \quad=$ Current Ratio

$\beta 2 \quad=$ Return on Assets

$\beta 3 \quad=$ Dept to Equity Ratio

\section{HASIL DAN PEMBAHASAN}

Pengujian Hosmer and Lemeshow's goodness of fit

Untuk menilai kelayakan model regresi dalam memprediksi digunakan uji Uji Chi Square Hosmer and Lemeshow, pengujian ini digunakan untuk menguji hipotesis :

$\mathrm{H}_{0}$ : Terdapat perbedaan antara klasifikasi yang diprediksikan dengan klasifikasi yang diamati.

$\mathrm{H}_{\mathrm{a}}$ : Tidak terdapat perbedaan antara klasifikasi yang dipresiksi dengan klasifikasi yang diamati.

Berikut ini adalah hasil pengujian Hosmer and Lemeshow's goodness of fit :

Tabel 1. Pengujian Hosmer and Lemeshow's goodness of fit

\begin{tabular}{lll}
\hline Chi - Square & Sig & Kesimpulan \\
379,743 & 0,0000 & Diterima \\
\hline
\end{tabular}

Sumber : Data diolah

Berdasarkan Dari tabel 1 diatas, menunjukkan bahwa hasil pengujian kesamaan prediksi model regresi logistik dengan data hasil observasi yang diperoleh dari nilai chi square sebesar 37,9743 dengan nilai signifikan sebesar 0,000. Dengan nilai signifikan yang lebih besar dari 0,05 maka tidak diperoleh adanya perbedaan antara prediksi model regresi logistik dengan data hasil observasi. Hal ini berarti bahwa model mampu memprediksi nilai observasinya atau dapat dikatakan model diterima karena model sesuai dengan hasil observasinya.

Hasil Pengujian Hipotesis

Pengujian hipotesis dilakukan untuk menjawab rumusan masalah dalam penelitian ini. Berikut tabel hasil pengujian hipotesis dalam penelitian ini :

Tabel 2. Hasil Analisis Regresi Logistic

\begin{tabular}{lccccl}
\hline Variable & Coefficient & Std. Error & Z-Statistic & Prob. & $\mathbf{H}_{\mathbf{a}}$ \\
\hline C & -1.440406 & 1.10387 & -1.304869 & 0.1919 & Ditolak \\
CR & -0.001257 & 0.001105 & -1.138014 & 0.2551 & Ditolak \\
ROA & 0.243274 & 0.061926 & 3.928456 & 0.0001 & Diterima \\
DER & -1.789589 & 1.108461 & -1.614481 & 0.1064 & Ditolak \\
\hline
\end{tabular}

Sumber: Eviews v.8

Berdasarkan tabel 2 diatas, bahwa variabel Current ratio memiliki nilai coefficient sebesar -0.001257 dengan nilai signifikansi sebesar $0.1919>0.05$,). Hal tersebut menunjukan bahwa variabel Current ratio tidak berpengaruh terhadap kondisi Financial Distress perusahaan manufaktur, sehingga menolak $\mathrm{H}_{1}\left(\mathrm{H}_{0}\right.$ diterima). Selain itu, variabel Debt to Equity Ratio memiliki nilai coefficient sebesar - 1.789589 dengan nilai signifikansi lebih besar sebesar $0.1064>0.05$. Hal tersebut menunjukan bahwa variabel Debt to Equity Ratio tidak berpengaruh terhadap kondisi Financial Distress dan analisis hipotesis menyimpulkan menolak $\mathrm{H}_{3}$ (menerima $\mathrm{H}_{0}$ ). Sedangkan variabel Return On Assets memiliki nilai coefficient sebesar 0.243274 dengan nilai signifikansi lebih kecil sebesar 0.001<0.05, yang menyatakan bahwa Return On Assets berpengaruh terhadap kondisi Financial Distress perusahaan manufaktur. Dengan demikian hipotesis analisis menunjukkan bahwa menerima $\mathrm{H}_{2}$ dan menolak $\mathrm{H}_{0}$. 


\section{Pembahasan}

Pengaruh Current Ratio Terhadap Financial Distress

Hasil analisis regresi logistic diatas dengan memprediksi kondisi financial distress bahwa current ratio tidak dapat memprediksi kondisi financial distress perusahaan manufaktur. Berdasarkan teori Current Ratio (Hery, 2015) perusahaan yang memiliki rasio lancar bernilai kecil mengindikasikan bahwa perusahaan tersebut memiliki modal kerja (asset lancar) yang sedikit untuk membayar kewajiban jangka pendeknya. Sebaliknya, apabila perusahaan memiliki rasio lancar yang tinggi belum tentu perusahaan tersebut dikatakan baik. Sehingga, rasio lancar yang tinggi dapat saja terjadi karena kurang efektifnya manajemen kas dan persediaan. Hasil penelitian ini sejalan dengan penelitian yang dilakukan oleh Saleh dan Sudiyatno (2013); Arwindadan Merkusiwati (2014); Kholidah dan Mufidah (2016); serta Sulastri dan Zannati (2018), yang menunjukan hasil bahwa Current Ratio tidak berpengaruh terhadap financial distress perusahaan.

Pengaruh Return On Asset (ROA) Terhadap Financial Distress

Dari hasil analisis statistik, pada variabel Return on Asset (ROA) menunjukkan bahwa nilai sig lebih kecil dari 0,05 sehingga disimpulkan ROA dapat memprediksi kondisi financial distress perusahaan manufaktur. Hery (2015) menjelaskann bahwa semakin tinggi hasil pengembalian atas asset (ROA), maka akan semakin besar jumlah laba bersih yang dihasilkan dari setiap rupiah dana yang tertanam dalam asset total. Sebaliknya, semakin rendah hasil pengembalian atas asset maka akan semakin rendah jumlah laba bersih yang dihasilkan dari setiap rupiah dana yang tertanam dalam total asset. Temuan ini sejalan dengan Saleh dan Sudiyatno (2013), Rahmadani, et al., (2014); Andre (2015); Setyobudi, et al., (2016); dan Anggraini (2017) yang menunjukan hasil bahwa Return on asset (ROA) Perpengaruh terhadap financial distress perusahaan.

Pengaruh Debt To Equity Ratio (DER) Terhadap Financial Distress.

Pada hasil analisis Debt to Equity Ratio (DER) yang menunjukkan bahwa nilai sig yang diperoleh lebih besar dari 0,05, maka DER tidak dapat memprediksi kondisi finacial distress dalam perusahaan manufaktur. Semakin tinggi nilai Debt to equity ratio maka akan semakin kecil jumlah modal pemilik yang dapat dijadikan sebagai jaminan utang (Hery, 2015). Ketentuan umumnya adalah bahwa debitor seharusnya memiliki Debt to equity ratio kurang dari 0,5 namun hal tersebut tidak dapat dijadikan ukuran yang utama karena tergantung terhadap ketentuan keputusan masing-masing perusahaan. Hasil penelitian ini sejalan dengan penelitian yang dilakukan oleh Saleh dan Sudiyatno (2013); Rahmadani, et al., (2014); Kholidah dan Mufidah (2016); Gonbenvy (2016), Anggraini (2017); yang menunjukan hasil bahwa Debt to Equity Ratio (DER) tidak berperpengaruh terhadap financial distress perusahaan.

\section{KESIMPULAN}

Berdasarkan hasil pengukuran financial distress melalui pendekatan metode Altman Z-Score, dapat dikonfirmasikan bahwa temuan dari penelitian ini menujukkan hanya Return on asset (ROA) berpengaruh terhadap kondisi financial distress perusahaan. Sedangkan hasil analisis lainnya untuk variabel Current ratio dan variabel Debt to Equity Ratio (DER) tidak berpengaruh terhadap kondisi Financial Distress perusahaan.

Implikasi

Penelitian ini diharapkan dapat memberikan kontribusi terhadap pihak manajerial perusahaan sebagai landasan informasi untuk mempertimbangkan keputusan manajemen dalam aspek keuangan. Selain itu, dapat menjadi bahan pertimbangan untuk calon investor dalam menentukan perusahaan yang akan menanamkan modalnya, bahwa kondisi keuangan perusahaan semakin sehat maka semakin layak calon investor untuk berinvestasi pada perusahaan tersebut. 
Keterbatasan

Keterbatasan penelitian ini yaitu variabel penelitian yang belum bervariasi dalam mengukur kinerja keuangan perusahaan, sehingga penelitian selanjutnya dapat dikembangkan faktor-faktor kinerja keuangan yang dapat memprediksi kondisi financial distress. Selain itu, perlu diperluas cakupan objek penelitian untuk sektor lainnya yang dinilai dari pertumbuhan perusahaan yang sedang menurun beberapa tahun terakhir seperti sektor pertambangan, perbankan syariah dan sektor lainnya agar hasil penelitian tersebut lebih bervariatif dalam memprediksi kondisi kebangkrutan sebuah perusahaan. Dalam memprediksi financial distress, terdapat beberapa pendekatan untuk menganalisis kebangkrutan, selain metode Atlman Z-score seperti metode Zmijewski, Springate, Grover, Tobins Q, Fulmer, Ohlson, dan Zeta.

\section{REFERENSI}

Andre, O., \& Taqwa, S. (2014). Pengaruh Profitabilitas, Likuiditas, dan Leverage Dalam Memprediksi Financial Distress (Studi Empiris Pada Perusahaan Aneka Industri yang Terdaftar di BEI Tahun 2006-2010). Wahana Riset Akuntansi, 2(1).

Anggraini, R. (2017). Analisis Profitabilitas, Likuiditas, Leverage, dan Inflasi Dalam Memprediksi Financial Distress pada Perusahaan Property dan Real Estate yang Terdaftar di Bursa Efek Indonesia.

Brigham, E. F., \& Houston, J. F. (2013). Dasar-dasar Manajemen Keuangan, Edisi 1, Buku 1. Jakarta: Salemba Empat.

Gobenvy, O. (2014). Pengaruh Profitabilitas, Financial Leverage dan Ukuran Perusahaan terhadap Financial Distress pada Perusahaan Manufaktur yang Terdaftar di Bursa Efek Indonesia Tahun 20092011. Jurnal Akuntansi, 2(1).

Hanifah, O. E., \& Purwanto, A. (2013). Pengaruh struktur corporate governance dan financial indicators terhadap kondisi financial distress. Diponegoro Journal of Accounting, 648-662.

Hariyani, D. S., \& Sujianto, A. (2018). Analisis Perbandingan Model Altman, Model Springate, dan Model Zmijewski Dalam Memprediksi Kebangkrutan Bank Syariah Di Indonesia. INVENTORY JURNAL AKUNTANSI. 1(2), 13-23.

Hery. (2015). Pengantar Akuntansi. Jakarta: Grasindo.

Hidayat, M. A., \& Meiranto, W. (2014). Prediksi Financial Distress Perusahaan Manufaktur di Indonesia (Studi Empiris pada Perusahaan Manufaktur yang Terdaftar di Bursa Efek Indonesia Periode 20082012). (Doctoral dissertation, Fakultas Ekonomika dan Bisnis).

Fahmi, I. (2017). Analisis laporan keuangan, edisi cetakan ke-6. Bandung: Alfabeta.

Kasmir. (2017). Analisis laporan keuangan, edisi cetakan ke-10. Jakarta: PT Raja Grafindo Persada.

Kholidah, A. N., Gumanti, T. A., \& Mufidah, A. (2016) . Analisis Rasio Keuangan Dalam Memprediksi Financial Distress Pada Perusahaan Sektor Industri Dasar dan Kimia Yang Terdaftar di BEI Tahun 20112015. BISMA, 10(3), 279-291.

Prihanthini, N. M. E. D., \& Sari, M. M. R. (2013). Prediksi Kebangkrutan Dengan Model Grover, Altman ZScore, Springate Dan Zmijewski Pada Perusahaan Food And Beverage Di Bursa Efek Indonesia. E-Jurnal Akuntansi, 417-435.

Putri, N. W. K. A., \& Merkusiwati, N. K. L. A. (2014). Pengaruh mekanisme corporate governance, likuiditas, leverage, dan ukuran perusahaan pada financial distress. E-Jurnal Akuntansi, 93-106.

Noviandri, T. (2015). Peranan analisis rasio keuangan dalam memprediksi kondisi financial distress perusahaan sektor perdagangan. Jurnal Ilmu Manajemen (JIM), 2(4).

Rahmadani, N., Edy Sujana, S. E., Darmawan, N. A. S., \& SE, A. (2014). Analisis Pengaruh Rasio Likuiditas, Rasio Profitabilitas, Rasio Rentabilitas Ekonomi dan Rasio Laverage Terhadap Prediksi Financial Distress (Studi Kasus Pada Sektor Perbankan Di Bursa Efek Indonesia Periode 2009-2013).JIMAT (Jurnal Ilmiah Mahasiswa Akuntansi) Undiksha, 2(1).

Saleh, A., \& Sudiyatno, B. (2013). Pengaruh Rasio Keuangan Untuk Memprediksi Probabilitas Kebangkrutan Pada Perusahaan Manufaktur Yang Terdaftar Di Bursa Efek Indonesia. Dinamika Akuntansi Keuangan dan Perbankan, 2(1). 
Setiawan, H., \& Amboningtyas, D. (2018). Finantial Ratio Analysis For Predicting Financial Conditions (Study on Telecommunication Companies Listed In Indonesia Stock Exchange Period 20102016). Journal of Management, 4(4).

Setyobudi, A., Amboningtyas, D., \& Yulianeu, Y. (2017). The Analysis Of Liquidity, Leverage, Profitability, And Firm Size Influence Toward The Financial Distress With Good Coorporate Governance As The Moderating Variabel In PT. Telekomunikasi Indonesia Tbk. And PT. Indosat Tbk. Journal of Management, 3(3).

Suryani dan Hendryadi. (2015). Metode Riset Kuantitatif: Teori Dan Aplikasi Pada Penelitian Bidang Manajemen Dan Ekonomi Islam, Edisi Pertama. Jakarta: Prenadamedia Group.

Sugiyono. (2014). Metode penelitian kuantitatif, kualitatif, dan R\&D. Cetakan ke-21. Bandung: Alfabeta.

Widhiari, N. L. M. A., \& Merkusiwati, N. K. L. A. (2015). Pengaruh rasio likuiditas, leverage, operating capacity, dan sales growth terhadap financial distress. E-Jurnal Akuntansi, 456-469.

Sulastri, E., dan Zannati, R. (2018). Prediksi financial distress dalam mengukur kinerja perusahaan manufaktur. Jurnal Manajemen Strategi dan Aplikasi Bisnis, 1(1), 27 - 36.

\section{PROFIL PENULIS}

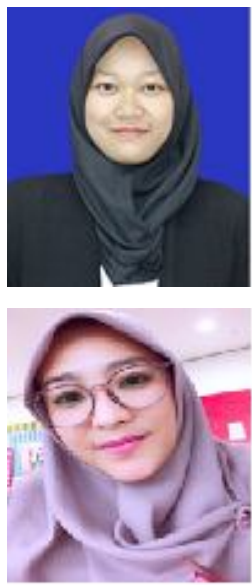

Nurul Fitri. Mahasiswa Akuntansi Fakultas Ekonomi dan Bisnis Universitas Islam Attahiriyah, Jakarta. Penulis masih aktif bekerja di SMA Negeri 16 Bekasi sebagai tata usaha sampai dengan saat ini. Email: nurulfitri977@gmail.com.

Rachma Zannati. Dosen jurusan Akuntansi, Sekolah Tinggi Ilmu Ekonomi Indonesia, Jakarta. Mengampu mata kuliah akuntansi, manajemen keuangan, statistik, serta metodologi penelitian. Penulis tertarik melakukan penelitian mengenai akuntansi dan ekonomi dan bisnis syariah. Email: rachmaznt@gmail.com 